\title{
Effects of Excessive Amounts of Dietary Iron on Pregnant Rats : Iron, Copper, Zinc, Manganese and Selenium Statuses in Mothers and Fetuses
}

\author{
Hajime Kumagal, Ryoji Kawashima* and Hideo Yano* \\ Faculty of Applied Biological Science, Hiroshima \\ University, Higashi-Hiroshima-shi 724 \\ * Faculty of Agriculture, Kyoto University, \\ Sakyo-ku, Kyoto-shi 606
}

(Received December 18, 1992)

\begin{abstract}
The effects of excessive amounts of dietary iron $(\mathrm{Fe})$ on pregnant rats which were fed adequate and deficient levels of dietary copper $(\mathrm{Cu})$ were investigated to measure trace mineral statuses in the dams and fetuses. Forty fernale Wistar rats with an average age of 46 days were fed diets containing adequate amounts of $\mathrm{Fe}$ and $\mathrm{Cu}$ $(43 \mathrm{mg} \mathrm{Fe}$ and $6.0 \mathrm{mg} \mathrm{Cu} / \mathrm{kg}$ ), adequate amounts of $\mathrm{Fe}$ and deficient amounts of $\mathrm{Cu}$ $(43 \mathrm{mg} \mathrm{Fe}$ and $0.6 \mathrm{mg} \mathrm{Cu} / \mathrm{kg}$ ), excessive amounts of $\mathrm{Fe}$ and adequate amounts of $\mathrm{Cu}$ (1165 mg Fe and $6.0 \mathrm{mg} \mathrm{Cu} / \mathrm{kg}$ ) and excessive amounts of $\mathrm{Fe}$ and deficient amounts of $\mathrm{Cu}$ (1165 $\mathrm{mg} \mathrm{Fe}$ and $0.6 \mathrm{mg} \mathrm{Cu} / \mathrm{kg}$ ) and mated. The rats were killed after a gestation period of 20 days and their blood, livers, kidneys, hearts, spleens, femurs and fetuses were sampled. Excessive amounts of dietary $\mathrm{Fe}$ decreased liver and heart weight in dams and increased individual fetal weight. The $\mathrm{Fe}$ concentrations in maternal and fetal tissues were increased by the $\mathrm{Fe}$ excessive diet. The concentrations of selenium (Se) in maternal livers, manganese $(\mathrm{Mn})$ in maternal livers and hearts, zinc $(\mathrm{Zn})$ in maternal serum and femurs, Se in fetal whole bodies and $\mathrm{Mn}$ in fetal whole bobies and livers were decreased by excessive amounts of dietary $\mathrm{Fe}$. Excessive amounts of dietary $\mathrm{Fe}$ in the diet did not decrease $\mathrm{Cu}$ concentrations in maternal and fetal tissues. The $\mathrm{Cu}$ concentrations in maternal and fetal tissues were decreased by deficient levels of dietary Cu. The Cu deficient diet for dams fed excessive amounts of dietary Fe decreased Fe concentrations in maternal serum and fetal whole bodies and livers.
\end{abstract}

Anim. Sci. Technol. (Jpn.) 64 (8): 780-789, 1993

Key words : excessive amount of iron, fetus, pregnancy, rat, trace mineral

Although $\mathrm{Fe}$ has important functions in animals since it is a component of hemoglobin, myoglobin, cytochrome, and the enzymes catalase and peroxidase, there is little convincing evidence that dietary Fe deficiency ever occurs in farm animals except for piglets ${ }^{25)}$. Conversely, excessive amounts of $\mathrm{Fe}$ in diets have influenced the performance in both farm and laboratory animals ${ }^{6,22,303}$. Copper concentra-

Anim. Sci. Technol. (Jpn.) 64 (8) : 780-789 780 tions of livers were greatly decreased in rats, sheep and cattle fed a excessive amount of $\mathrm{Fe}^{3,5,28)}$. Zinc and $\mathrm{Mn}$ metabolisms in rats and cattle were also affected by a large amount of Fe ingestion ${ }^{11,12,22)}$.

Deficiencies of trace minerals during gestation have profound effects on mineral status and cause disorders in dams and their offsprings. Deficiencies of $\mathrm{Cu}, \mathrm{Zn}$ and $\mathrm{Mn}$ in 
ruminants resulted in retarded growth and congenital malformations in newborns ${ }^{2,9,193}$. Selenium deficiency in cows caused retained placenta in dams and nutritional muscular dystrophy in calves ${ }^{1,14}$. Since $\mathrm{Fe}$ demand is increased during the latter period of a pregnancy by the presence of a fetus, many researches on $\mathrm{Fe}$ deficiency during gestation have been done ${ }^{18,24,27)}$. However, there are few studies on the effects of high levels of dietary $\mathrm{Fe}$ and the interactive ef fects of dietary $\mathrm{Fe}$ and $\mathrm{Cu}$ on the performance and mineral statuses in pregnant animals and their offsprings. Rats were used for this experiment to investigate the effects of excessive amounts of dietary $\mathrm{Fe}$ on pregnant dams and their fetuses. The rats were fed adequate or deficient levels of dietary $\mathrm{Cu}$ and their trace mineral statuses were examined.

\section{Materials and Methods}

Animals and diets: Forty female Wistar rats, weaned at the age of 28 days, were raised until they were 3437 days old on a commercial diet for growing rats (MF, Oriental Yeast Co., LTD). The animals were accustomed to a purified diet containing $43 \mathrm{mg} \mathrm{Fe}$ and $6.0 \mathrm{mg}$ $\mathrm{Cu} / \mathrm{kg}$ for $8-13$ days. The following 4 purified diets were given when the rats were 44-48 days old; a diet with adequate amounts of $\mathrm{Fe}$ and $\mathrm{Cu}$ (FeACuA, $43 \mathrm{mg} \mathrm{Fe}$ and $6.0 \mathrm{mg} \mathrm{Cu} / \mathrm{kg}$, $\mathrm{n}=8$ ), a diet with adequate amounts of $\mathrm{Fe}$ and deficient amounts of $\mathrm{Cu}$ (FeACuD, $43 \mathrm{mg} \mathrm{Fe}$ and $0.6 \mathrm{mg} \mathrm{Cu} / \mathrm{kg}, \mathrm{n}=12$ ), a diet with excessive amounts of $\mathrm{Fe}$ and adequate amounts of $\mathrm{Cu}$ (FeECuA, $1165 \mathrm{mg} \mathrm{Fe}$ and $6.0 \mathrm{mg} \mathrm{Cu} / \mathrm{kg}$, $\mathrm{n}=8$ ) and a diet with excessive amounts of $\mathrm{Fe}$ and feficient amounts of $\mathrm{Cu}(\mathrm{FeECuD}, 1165 \mathrm{mg}$ $\mathrm{Fe}$ and $0.6 \mathrm{mg} \mathrm{Cu} / \mathrm{kg}, \mathrm{n}=12$ ). The composition of a basal diet is shown in Table 1. Ferric citrate and copper carbonate monohydrate were used to compose each diet. Groups of four animals each were housed in a suspended stainless-steel cage in a room controlled through temperature, light and humidity $\left(22^{\circ} \mathrm{C}\right.$,
Table 1. Composition of a basal diet

\begin{tabular}{lc}
\hline \multicolumn{1}{c}{ Component } & $\%$ \\
\hline Corn starch & 41.5 \\
Milk casein & 25.0 \\
$\alpha$-Starch & 10.0 \\
Cellulose powder & 8.0 \\
Vegetable oil & 6.0 \\
Granulated sugar & 5.0 \\
Mineral mixture $^{1)}$ & 3.5 \\
Vitamin mixture $^{2)}$ & 1.0 \\
\hline
\end{tabular}

"Oriental Yeast Co., LTD. Tokyo. Modified AIN -76 mineral mixture without iron and copper $(\mathrm{g} /$ $\mathrm{kg}$ of diet) : $\mathrm{CaHPO}_{4}, 17.5 ; \mathrm{NaCl}, 2.59 ; \mathrm{K}_{3} \mathrm{C}_{6} \mathrm{H}_{5} \mathrm{O}_{7}$. $\mathrm{H}_{2} \mathrm{O}, 7.7 ; \mathrm{K}_{2} \mathrm{SO}_{4}, 1.82 ; \mathrm{MgO}, 0.84 ; \mathrm{MnCO}_{3}, 0.12$; $\mathrm{ZnCO}_{3}, 0.056 ; \mathrm{Na}_{2} \mathrm{SeO}_{3} \cdot 5 \mathrm{H}_{2} \mathrm{O}, 0.00035 ; \mathrm{KIO}_{3}$ 0.00035 ; and $\mathrm{CrK}\left(\mathrm{SO}_{1}\right)_{2} \cdot 12 \mathrm{H}_{2} \mathrm{O}, 0.019$

${ }^{2}$ Oriental Yeast Co., LTD. Tokyo. AIN-76 vitamin mixture ( $\mathrm{mg} / \mathrm{kg}$ of diet) : choline bitartrate, 2000 ; vitamin $K_{3}, 0.05$; vitamin $B_{1}$ hydrochloride, 6; vitamin $B_{2}, 6$; vitamin $B_{6}$ hydrochloride, 7; vitammin $B_{12}, 0.01 ; D$-biotin, 0.2 ; folic acid, 2 ; calcium pantothenate, 16 ; nicotinic acid, 30 ; vitamin A acetate $4000 \mathrm{IU} / \mathrm{kg}$ diet and vitamin $\mathrm{D}_{3}$ $1000 \mathrm{IU} / \mathrm{kg}$ diet.

a cycle of 13 hours of light and 11 hours of darkness and $60 \%$ humidity). The diet and ion-exchanged water were fed ad libitum. Body weights were recorded weekly. The vaginal smears of rats were tested every day after the rats were allocated the experimental diets. When each rat had reached its pre-estrus day after turning 51-58 days old, every female rat was removed overnight and mated with a male Wistar rat. Day 0 of gestation was assumed when sperms were observed in the smear.

Sample procedures: On the 20th day of gestation, the rats were starved for 24 hours and given an intraperitioneal injection of pentobarbital. Blood samples from the abdominal aorta were taken. The blood was then transferred into centrifuge tubes. A small portion of the blood sample was used for measuring the hematocrits and the rest of the blood sample was centrifuged for 15 minutes at $3000 \mathrm{~g}$. Maternal livers, kidneys, hearts and 
spleens were removed, trimmed free of fat, washed with saline and weighed after wiping. The right femurs from mothers were removed, trimmed free of connective tissue, dried for 48 hours at $120^{\circ} \mathrm{C}$ and weighed. The uteri were opened and the fetuses were removed. The fetuses were then washed with saline, examined for apparent fetal malformations and weighed after wiping. The fetuses in the right uterine horns were decapitated, the hematocrits were measured and the livers were removed. The fetuses in the left uterus were freeze-dried and ground by a coffee mill. The samples of serum and tissues from dams were transferred into polypropylene tubes and stored in a freezer at $-20^{\circ} \mathrm{C}$ for later mineral analyses.

Analyses: Soft tissues and serum were digested by a $4: 1$ mixture of $60 \%$ nitric and perchloric acids. Femur samples were digested in a muffle for 6 hours at $600^{\circ} \mathrm{C}$ and dissolved in $1 \mathrm{~N}$ hydrochloric acid. The $\mathrm{Fe}, \mathrm{Cu}, \mathrm{Zn}$ and $\mathrm{Mn}$ concentrations in tissue and serum samples were analysed by flame atomic absorption spectrophotometry. The concentrations of Se were analysed by fluorometrical spectrophotometry through the WATKINSON ${ }^{29)}$ method.

Statistics: The values were statistically analysed by the following mathematical model :

$$
\mathrm{Y}=\mu+\mathrm{F}_{\mathrm{i}}+\mathrm{C}_{\mathrm{j}}+(\mathrm{FC})_{i j}+\mathrm{E}_{\mathrm{ijk}}
$$

where:

$\mathrm{Y}$ : each value

$\mu$ : the overall mean

$F_{i}$ : the effect associated with $\mathrm{Fe}$ level in the diet

$\mathrm{C}_{\mathrm{j}}$ : the effect associated with $\mathrm{Cu}$ level in the diet

(FC) ${ }_{i j}$ : the interaction effect between $\mathrm{Fe}$ and $\mathrm{Cu}$ levels in the diet

\section{$E_{i j k}:$ residual}

All statistical analyses were conducted through the least square analysis of variance procedure by HARVEY ${ }^{13}$.

\section{Results}

One rat fed an $\mathrm{FeACuD}$ diet, 2 rats fed an FeECuA diet and 5 rats fed an FeECuD diet did not conceive in the first mating. Two rats from the FeECuA and FeECuD diets, respectively, conceived in the second mating. One rat fed the FeACuD diet and 3 rats fed the FeEDuD diet, which missed conception in the first mating, did not conceive in the second mating as well. These rats were removed from the experiment.

There were no significant differences in

Table 2. Daily gain during pregnacy and tissue weight of dams

\begin{tabular}{|c|c|c|c|c|c|c|c|}
\hline \multirow{2}{*}{ Item } & \multicolumn{4}{|c|}{ Diet } & \multicolumn{3}{|c|}{$\begin{array}{l}\text { Significance of } \\
\text { differences }\end{array}$} \\
\hline & $\begin{array}{c}\mathrm{FeACuA} \\
(\mathrm{n}=8)\end{array}$ & $\begin{array}{c}\text { FeACuD } \\
(\mathrm{n}=11)\end{array}$ & $\begin{array}{c}\text { FeECuA } \\
(\mathrm{n}=8)\end{array}$ & $\begin{array}{c}\text { FeECuD } \\
(\mathrm{n}=9)\end{array}$ & $\mathrm{Fe}$ & $\mathrm{Cu}$ & $\mathrm{Fe} \times \mathrm{Cu}$ \\
\hline \multicolumn{8}{|c|}{ Daily gain during pregnancy $(\mathrm{g})$} \\
\hline & $7.7 \pm 0.3^{2)}$ & $7.1 \pm 0.2$ & $7.2 \pm 0.3$ & $7.4 \pm 0.4$ & NS & NS & NS \\
\hline \multicolumn{8}{|c|}{ Tissue weight ${ }^{3 /}(\mathrm{g})$} \\
\hline Liver & $13.6 \pm 0.8$ & $13.4 \pm 0.6$ & $12.2 \pm 0.5$ & $12.2 \pm 0.6$ & * & NS & NS \\
\hline Kidney & $1.77 \pm 0.10$ & $1.79 \pm 0.07$ & $1.72 \pm 0.06$ & $1.59 \pm 0.06$ & NS & NS & NS \\
\hline Heart & $0.98 \pm 0.05$ & $0.99 \pm 0.04$ & $0.89 \pm 0.04$ & $0.90 \pm 0.04$ & ${ }^{*}$ & NS & NS \\
\hline Spleen & $0.50 \pm 0.03$ & $0.49 \pm 0.02$ & $0.46 \pm 0.02$ & $0.50 \pm 0.04$ & NS & NS & NS \\
\hline Femur & $0.39 \pm 0.02$ & $0.41 \pm 0.01$ & $0.38 \pm 0.01$ & $0.40 \pm 0.01$ & NS & NS & NS \\
\hline
\end{tabular}

1)*, $\mathrm{P}<0.05 ; \mathrm{NS}$, not significant.

${ }^{2)}$ Least square means \pm standard error of means.

3) Values of liver, kidney, heart and spleen are wet weight and those of femurs are dry weight. 
Table 3. Hematocrit and mineral concentrations in serum and tissues of dams

\begin{tabular}{|c|c|c|c|c|c|c|c|}
\hline \multirow{2}{*}{ Item } & \multicolumn{4}{|c|}{ Diet } & \multicolumn{3}{|c|}{$\begin{array}{c}\text { Significance of } \\
\text { differences }\end{array}$} \\
\hline & $\begin{array}{c}\text { FeACuA } \\
(n=8)\end{array}$ & $\begin{array}{c}\mathrm{FeACuD} \\
(\mathrm{n}=11)\end{array}$ & $\underset{(n=8)}{\text { FeECuA }}$ & $\begin{array}{c}\mathrm{FeECuD} \\
(\mathrm{n}=9)\end{array}$ & $\mathrm{Fe}$ & $\mathrm{Cu}$ & $\mathrm{Fe} \times \mathrm{Cu}$ \\
\hline Hematocrit & $28.1 \pm 1.3^{21}$ & $30.5 \pm 1.1$ & $34.9 \pm 1.0$ & $35.6 \pm 0.9$ & $* *$ & NS & NS \\
\hline \multicolumn{8}{|l|}{ Serum $(\mu \mathrm{g} / \mathrm{m} l)$} \\
\hline Iron & $0.28 \pm 0.03$ & $0.39 \pm 0.05$ & $1.75 \pm 0.30$ & $0.65 \pm 0.13$ & $* *$ & ** & $* *$ \\
\hline Copper & $1.51 \pm 0.13$ & $0.23 \pm 0.03$ & $1.51 \pm 0.08$ & $0.24 \pm 0.03$ & NS & $* *$ & NS \\
\hline Zinc & $1.08 \pm 0.02$ & l. $46 \pm 0.05$ & $1.05 \pm 0.06$ & $1.17 \pm 0.05$ & ** & $* *$ & $* *$ \\
\hline \multicolumn{8}{|c|}{ Liver $(\mu \mathrm{g} / \mathrm{g}$ on a wet basis $)$} \\
\hline Iron & $29.2 \pm 1.0$ & $50.3 \pm 5.0$ & $171.2 \pm 25.0$ & $266.8 \pm 26.8$ & $* *$ & $* *$ & * \\
\hline Copper & $4.2 \pm 0.1$ & $1.8 \pm 0.1$ & $4.7 \pm 0.1$ & $2.1 \pm 0.1$ & $* *$ & ** & NS \\
\hline Zinc & $17.4 \pm 0.2$ & $17.2 \pm 0.3$ & $18.2 \pm 0.3$ & $17.5 \pm 0.5$ & NS & NS & NS \\
\hline Manganese & $3.7 \pm 0.1$ & $3.7+0.1$ & $3.0+0.2$ & $3.1+0.1$ & ** & NS & NS \\
\hline Selenium & $0.37+0.02$ & $0.38 \pm 0.03$ & $0.31 \pm 0.02$ & $0.30 \pm 0.02$ & ** & NS & NS \\
\hline \multicolumn{8}{|c|}{ Kidney ( $\mu \mathrm{g} / \mathrm{g}$ on a wet basis) } \\
\hline Iron & $36.5 \pm 1.5$ & $35.7 \pm 1.4$ & $55.3 \pm 1.6$ & $51.6 \pm 2.9$ & $* *$ & NS & NS \\
\hline Copper & $6.0 \pm 0.5$ & $3.2 \pm 0.1$ & $7.6 \pm 1.1$ & $3.4 \pm 0.1$ & NS & $* *$ & NS \\
\hline Zinc & $24.2 \pm 0.2$ & $23.1 \pm 0.4$ & $23.8 \pm 0.8$ & $23.2 \pm 0.5$ & NS & NS & NS \\
\hline Manganese & $1.02 \pm 0.02$ & $1.00 \pm 0.04$ & $1.00 \pm 0.05$ & $1.01=0.04$ & NS & NS & NS \\
\hline \multicolumn{8}{|c|}{ Heart $(\mu \mathrm{g} / \mathrm{g}$ on a wet basis) } \\
\hline Iron & $55.1 \pm 3.1$ & $55.2 \pm 1.7$ & $66.9 \pm 1.4$ & $65.8 \pm 2.6$ & ** & NS & NS \\
\hline Copper & $5.2 \pm 0.1$ & $4.1 \pm 0.1$ & $5.3 \pm 0.1$ & $4.3 \pm 0.1$ & NS & ** & NS \\
\hline Zinc & $17.4 \pm 0.4$ & $16.7 \pm 0.3$ & $16.9 \pm 0.5$ & $16.1 \pm 0.3$ & NS & NS & NS \\
\hline Manganese & $0.38 \pm 0.02$ & $0.45 \pm 0.02$ & $0.36 \pm 0.02$ & $0.40 \pm 0.01$ & * & ** & NS \\
\hline \multicolumn{8}{|c|}{ Spleen $(\mu \mathrm{g} / \mathrm{g}$ on a wet basis) } \\
\hline Iron & $116.4 \pm 7.9$ & $104.5 \pm 5.5$ & $259.0 \pm 44.3$ & $282.0 \pm 79.4$ & ** & NS & NS \\
\hline Copper & $1.31 \pm 0.06$ & $0.53 \pm 0.06$ & $1.21 \pm 0.08$ & $0.73 \pm 0.11$ & NS & ** & NS \\
\hline Zinc & $20.4 \pm 0.2$ & $20.0 \pm 0.2$ & $20.4 \pm 0.3$ & $18.8 \pm 1.3$ & NS & NS & NS \\
\hline Manganese & $1.21 \pm 0.10$ & $1.22 \pm 0.14$ & $1.26 \pm 0.09$ & $0.99 \pm 0.08$ & NS & NS & NS \\
\hline \multicolumn{8}{|c|}{ Femur ( $\mu \mathrm{g} / \mathrm{g}$ on a dry basis) } \\
\hline Iron & $39.4 \pm 2.0$ & $39.7 \pm 2.1$ & $79.3 \pm 2.8$ & $101.5 \pm 30.3$ & ** & NS & NS \\
\hline Copper & $6.7 \pm 0.6$ & $5.9 \pm 0.4$ & $6.5 \pm 0.1$ & $5.8 \pm 0.2$ & NS & NS & NS \\
\hline Zinc & $229.1 \pm 14.8$ & $221.9 \pm 5.6$ & $200.7 \pm 2.7$ & $207.3 \pm 5.2$ & * & NS & NS \\
\hline Manganese & $3.5 \pm 0.2$ & $3.7 \pm 0.1$ & $3.3 \pm 0.1$ & $3.4 \pm 0.1$ & NS & NS & NS \\
\hline
\end{tabular}

1) * $\mathrm{P}<0.05 ; * *, \mathrm{P}<0.01 ; \mathrm{NS}$, not significant.

${ }^{2)}$ Least square means \pm standard error of means.

weight gain of maternal rats between the treatment groups during pregnancy. The weights of livers and hearts from rats fed $\mathrm{Fe}$ excessive diets were significantly lower than those of rats fed an $\mathrm{Fe}$ adequate diets $(\mathrm{p}<0.05$ ) (Table 2). No significant differences of tissue weights was observed between the rats fed $\mathrm{Cu}$ deficient diets and those fed $\mathrm{Cu}$ adequate diets.
Excessive amounts of Fe intake significantly increased hematocrits and Fe concentrations in serum, livers, kidneys, hearts, spleens and femurs from mothers $(p<0.01)$ (Table 3$)$. Notably, $\mathrm{Fe}$ concentrations in livers from mothers fed excessive amounts of $\mathrm{Fe}$ were 5 times higher than those fed adequate amounts of Fe. The high levels of dietary Fe signifi- 
Table 4. Fetal number, total fetal weight and individual fetal weight

\begin{tabular}{|c|c|c|c|c|c|c|c|}
\hline \multirow{2}{*}{ Item } & \multicolumn{4}{|c|}{ Diet } & \multicolumn{3}{|c|}{$\begin{array}{l}\text { Significance of } \\
\text { differences }^{\text {I) }}\end{array}$} \\
\hline & $\underset{(n=8)}{\mathrm{FeACuA}}$ & $\underset{(n=11)}{\text { FeACuD }}$ & $\begin{array}{c}\text { FeECuA } \\
(n=8)\end{array}$ & $\begin{array}{c}\mathrm{FeECuD} \\
(\mathrm{n}=9)\end{array}$ & $\mathrm{Fe}$ & $\mathrm{Cu}$ & $\mathrm{Fe} \times \mathrm{Cu}$ \\
\hline Fetal Number & $13.6 \pm 0.8^{21}$ & $11.6 \pm 0.8$ & $12.5 \pm 0.6$ & $12.7 \pm 0.7$ & NS & NS & NS \\
\hline \multicolumn{8}{|l|}{ Fetal weight $(g)$} \\
\hline Total weight & $52.7 \pm 2.9$ & $42.9 \pm 2.7$ & $53.6 \pm 3.4$ & $52.2 \pm 3.7$ & NS & NS & NS \\
\hline Individual weight & $3.92 \pm 0.08$ & $3.73 \pm 0.15$ & $4.27 \pm 0.08$ & $4.09 \pm 0.10$ & $* *$ & NS & NS \\
\hline
\end{tabular}

1)**, $\mathrm{P}<0.01 ; \mathrm{NS}$, not significant.

${ }^{21}$ Least square means \pm standard error of means.

Table 5. Hematocrit and mineral concentrations and contents in fetuses

\begin{tabular}{|c|c|c|c|c|c|c|c|}
\hline \multirow{2}{*}{ Item } & \multicolumn{4}{|c|}{ Diet } & \multicolumn{3}{|c|}{$\begin{array}{l}\text { Significance } \\
\text { of differeces }\end{array}$} \\
\hline & $\begin{array}{c}\text { FeACuA } \\
(\mathrm{n}=8)\end{array}$ & $\begin{array}{c}\mathrm{FeACuD} \\
(\mathrm{n}=11)\end{array}$ & $\begin{array}{c}\text { FeECuA } \\
(n=8)\end{array}$ & $\begin{array}{c}\text { FeECuD } \\
(n=9)\end{array}$ & \multirow{2}{*}{$\frac{\mathrm{Fe}}{* *}$} & \multirow{2}{*}{$\frac{\mathrm{Cu}}{\mathrm{NS}}$} & \multirow{2}{*}{$\frac{\mathrm{Fe} \times \mathrm{Cu}}{\mathrm{NS}}$} \\
\hline Hematocrit & $24.1 \pm 0.7^{21}$ & $25.0 \pm 1.4$ & $36.7 \pm 1.0$ & $34.4 \pm 1.5$ & & & \\
\hline \multicolumn{8}{|c|}{ Whole body $(\mu \mathrm{g} / \mathrm{g}$ on a wet basis) } \\
\hline Iron & $19.2 \pm 0.9$ & $21.1 \pm 1.1$ & $42.7 \pm 2.4$ & $36.9 \pm 2.3$ & $* *$ & NS & $* *$ \\
\hline Copper & $1.86 \pm 0.04$ & $0.41 \pm 0.03$ & $2.06 \pm 0.09$ & $0.34 \pm 0.04$ & NS & $* *$ & $* *$ \\
\hline Zinc & $16.3 \pm 0.3$ & $14.9 \pm 0.2$ & $15.4 \pm 0.5$ & $15.9 \pm 0.9$ & NS & NS & NS \\
\hline Manganese & $0.36 \pm 0.02$ & $0.54 \pm 0.02$ & $0.30 \pm 0.01$ & $0.33 \pm 0.03$ & $* *$ & $* *$ & *** \\
\hline Selenium & $0.116 \pm 0.002$ & $0.112 \pm 0.002$ & $0.093 \pm 0.004$ & $0.104 \pm 0.005$ & ** & NS & NS \\
\hline \multicolumn{8}{|c|}{ Whole body ( $\mu \mathrm{g}$ per head) } \\
\hline Iron & $76.4 \pm 4.3$ & $78.8 \pm 5.5$ & $184.1 \pm 12.7$ & $154.0 \pm 11.6$ & $* *$ & NS & NS \\
\hline Copper & $7.4 \pm 0.2$ & $1.5 \pm 0.2$ & $8.8 \pm 0.5$ & $1.4 \pm 0.2$ & NS & $* *$ & $* *$ \\
\hline Zinc & $64.9 \pm 1.6$ & $56.0 \pm 2.9$ & $66.3 \pm 2.9$ & $66.5 \pm 5.5$ & NS & NS & NS \\
\hline Manganese & $1.41 \pm 0.06$ & $2.00 \pm 0.10$ & $1.31 \pm 0.04$ & $1.37 \pm 0.11$ & $* *$ & $* *$ & *** \\
\hline Selenium & $0.46 \pm 0.01$ & $0.43 \pm 0.02$ & $0.40 \pm 0.02$ & $0.42 \pm 0.02$ & $*$ & NS & NS \\
\hline \multicolumn{8}{|c|}{ Liver ( $\mu \mathrm{g} / g$ on a wet basis) } \\
\hline Iron & $58.0 \pm 2.0$ & $56.8 \pm 4.6$ & $181.9 \pm 10.0$ & $134.1 \pm 7.2$ & $* *$ & ** & $* *$ \\
\hline Copper & $13.0 \pm 0.6$ & $1.0 \pm 0.2$ & $14.1 \pm 0.6$ & $0.8 \pm 0.1$ & NS & ** & NS \\
\hline $\operatorname{Zinc}$ & $59.8 \pm 3.0$ & $45.7 \pm 2.0$ & $58.1 \pm 3.5$ & $48.8 \pm 2.1$ & NS & ** & NS \\
\hline Manganese & $0.86 \pm 0.04$ & $1.18 \pm 0.05$ & $0.44 \pm 0.03$ & $0.63 \pm 0.04$ & $* *$ & $* *$ & NS \\
\hline
\end{tabular}

1) * $\mathrm{P}<0.05 ;{ }^{* *}, \mathrm{P}<0.01$; NS, not significant.

${ }^{2)}$ Least square means \pm standard error of means.

cantly decreased the concentrations of $\mathrm{Zn}$. in serum $(p<0.01), M n$ and Se in livers $(p<0.01)$, $\mathrm{Mn}$ in hearts $(\mathrm{p}<0.05)$ and $\mathrm{Zn}$ in femurs $(p<0.05)$ and significantly increased the concentrations of $\mathrm{Cu}$ in livers $(p<0.01)$. The deficient levels of dietary $\mathrm{Cu}$ significantly decreased $\mathrm{Cu}$ concentrations in the serum, livers, kidneys, hearts and spleens from dams $(p<0.01)$. The concentrations of $\mathrm{Zn}$ in the serum and $\mathrm{Mn}$ in the hearts were significantly increased by the deficient levels of $\mathrm{Cu}$ in the diet $(\mathbf{p}<0.01)$. An interactive effect of dietary $\mathrm{Fe}$ and $\mathrm{Cu}$ was observed in the concentrations of $\mathrm{Fe}$ in the serum $(\mathrm{p}<0.01)$ and livers $(p<0.05)$ of dams. Low $\mathrm{Cu}$ intake markedly decreased the serum $\mathrm{Fe}$ concentrations and 
increased the liver $\mathrm{Fe}$ concentrations in dams fed excessive amounts of dietary Fe.

No apparent malformation was observed in the fetuses. There were no significant effects of dietary $\mathrm{Fe}$ and $\mathrm{Cu}$ on the fetal numbers (Table 4). Individual fetal weights of excess Fe groups were significantly heavier than those of adequate $F e$ groups $(p<0.01)$.

Significant effects of dietary $F e$ on fetal hematocrits and $\mathrm{Fe}$ concentrations in fetal whole bodies and livers were observed $(p<0.01)$ (Table 5). Excessive amount of Fe in the diet significantly decreased the concentrations and contents of $\mathrm{Mn}$ in fetal whole bodies and the Mn concentrations in fetal livers $(p<0.01)$. Both the concentrations and contents of Se in fetal whole bodies were significantly decreased by the $F$ excessive diets ( $p<0.01$ and $p<0.05$ ). The $\mathrm{Cu}$ deficient diet remarkably decreased the $\mathrm{Cu}$ concentrations in fetuses. The $\mathrm{Cu}$ concentrations within fetal whole bodies and livers of the $\mathrm{Cu}$ deficient groups compared to those of the $\mathrm{Cu}$ adequate groups were $20 \%$ and $7 \%$, respectively. Low $\mathrm{Cu}$ intake significantly increased $\mathrm{Mn}$ concentrations in fetal whole bodies and livers $(p<0.01)$ and decreased $\mathrm{Zn}$ concentrations in fetal livers $(p<0.01)$. Interactive effects of dietary $\mathrm{Fe}$ and $\mathrm{Cu}$ were observed in the $\mathrm{Fe}$ concentrations of fetal whole bodies and livers $(p<0.01)$. The $\mathrm{Fe}$ concentrations of fetal whole bodies and livers from dams fed excessive amounts of $\mathrm{Fe}$ were decreased by low $\mathrm{Cu}$ concentrations in the diet.

\section{Discussion}

Although the high levels of dietary Fe did not affect weight gain, it reduced liver and heart weights in dams. A previous study indicated that rats fed the diet supplemented with $2.5 \% \mathrm{Fe}$ in the form of carbonyl iron for 11-12 weeks reduced food intake and weight gain $^{30)}$. The Fe levels of the $\mathrm{Fe}$ excessive diets in this experiment were much lower than that in the previous study. It is likely that 1000 $\mathrm{mg} / \mathrm{kg} \mathrm{Fe}$ in the diet was not toxic enough to affect the maternal weight gain but had an effect on the liver and heart weights.

The significantly higher individual fetal weights from dams fed excessive amounts of Fe compared to those from dams fed adequate amounts of $\mathrm{Fe}$ were observed. The increased fetal weights might have been caused by an increased nutrient flow from the dams to the fetuses since the dry matter weights of fetuses in $\mathrm{Fe}$ excess groups were also higher than those in $\mathrm{Fe}$ adequate groups (The data were not shown.). However, the mechanism whereby excessive amounts of dietary $\mathrm{Fe}$ has this effect is unknown.

The serum $\mathrm{Fe}$ concentrations of rats fed FeACuA diets were much lower than those of non-pregnant female rats in a previous experiment even though the dietary mineral composition of the present experiment was similar to that of the previous one ${ }^{17}$. Serum $\mathrm{Fe}$ concentrations in dams decrease in late pregnancy ${ }^{20,27)}$. The lower serum Fe concentrations of rats fed FeACuA diets compared to those of previous studies might be due to the gestation.

The $\mathrm{Fe}$ excessive diet influenced not only the concentrations of $\mathrm{Fe}$ in maternal tissues but also those in fetal tissues. The concentrations of $\mathrm{Fe}$ in the whole bodies and livers of fetuses from mothers fed the $\mathrm{Fe}$ excessive diet were significantly higher than those from mothers fed the $\mathrm{Fe}$ adequate diet. The supplementary $\mathrm{Fe}$ was most likely transferred to fetuses across placentas and deposited in fetal tissues. The higher hematocrits in fetuses might be due to the increased Fe flow into fetuses.

The large amounts of $\mathrm{Fe}$ did not reduce $\mathrm{Cu}$ concentrations in any maternal tissues. Conversely, it significantly increased maternal liver $\mathrm{Cu}$ concentrations. The result of this study conflicts with those of previous studies. GORDON and ELLERSIECK ${ }^{11)}$ reported that liver $\mathrm{Cu}$ concentrations in male weanling rats fed a $270 \mathrm{mg} \mathrm{Fe} / \mathrm{kg}$ diet for 21 days were significantly lower than those fed a $90 \mathrm{mg} \mathrm{Fe} / \mathrm{kg}$ diet. 
Storey and GREGER ${ }^{23)}$ demonstrated that liver $\mathrm{Cu}$ concentrations in male weanling rats fed a $1500 \mathrm{mg} \mathrm{Fe} / \mathrm{kg}$ diet were significantly lower than those fed a $35 \mathrm{mg} \mathrm{Fe} / \mathrm{kg}$ diet during 1,18 and 25 day experiments. However, liver $\mathrm{Cu}$ concentrations in male and female weanling rats fed a $300 \mathrm{mg} \mathrm{Fe} / \mathrm{kg}$ diet for 42 days were not different from those fed a $50 \mathrm{mg} \mathrm{Fe} / \mathrm{kg}$ diet $^{17)}$. BREMNER and PrICE ${ }^{3)}$ reported that liver $\mathrm{Cu}$ concentrations in male weanling rats fed a $500 \mathrm{mg} \mathrm{Fe} / \mathrm{kg}$ diet were decreased within 2 weeks and recovered within 6 weeks. They suggested that the rats adapted to the continual intake of a large amount of $\mathrm{Fe}$. The experimental period of this study was averaged 31 days which is longer than those of studies conducted by Gordon and EllersiecK ${ }^{11}$ and STOREY and GREGER ${ }^{23)}$. There is a possibility that the difference of experimental period caused the inconsistent results among the experiments. Besides, there is another possibility that the inconsistency might be due to the physiological difference of rats. A previous study indicated that the uptake of ${ }^{64} \mathrm{Cu}$ was more efficient in pregnant rats than nonpregnant rats ${ }^{7}$. The depletion of Cu caused by Fe loading might be less severe in pregnant rats than weanling rats.

It has not been observed that the concentrations of $\mathrm{Se}$ in the livers of rats fed large amounts of $\mathrm{Fe}$ were lower than those fed adequate amounts of $\mathrm{Fe}$. As a component of glutathione peroxidase, Se plays an important role in the defense system against peroxidative damage to lipid membranes ${ }^{21)}$. Previous evidence in vivo indicated that Fe overload caused an accumulation of large quantities of $\mathrm{Fe}$ in cells and tissues. Lipid peroxide formation also increased during the Fe loading ${ }^{8}$. In the present study, Fe concentrations in the livers of $\mathrm{Fe}$ excess groups were 5 times higher than those of $\mathrm{Fe}$ adequate groups. Though the extent of lipid peroxidation in livers was not measured, the $\mathrm{Fe}$ accumulation in livers might have increased Se demand to protect mem- branes against peroxidative damage.

The excessive amounts of $\mathrm{Fe}$ in diets decreased the concentrations of $\mathrm{Mn}$ in maternal livers and hearts. High concentrations of $\mathrm{Fe}$ in diets decreased $\mathrm{Mn}$ absorption in the duodenum of rats $^{12}$. The lowered Mn concentrations in the tissues of dams were caused by the excessive amounts of $\mathrm{Fe}$.

The contents of $\mathrm{Se}$ and $\mathrm{Mn}$ in fetal whole bodies in the excessive $\mathrm{Fe}$ groups were lower than those of fetuses in the adequate $\mathrm{Fe}$ groups in spite of the increased individual fetal weights. It is likely to indicate that the transfers of Se and $\mathrm{Mn}$ from dams to fetuses were peculiarly depressed by the excessive amounts of dietary $\mathrm{Fe}$ for dams though a nutrient flow from dams to fetuses were increased. Previous reports suggested that the Se and Mn transfers from dams to fetuses were influenced by maternal Se and Mn statuses ${ }^{15,16}$. The low Se and Mn contents in fetuses in the excessive Fe groups might have been due to the low Se and Mr statuses in their dams.

The large amounts of $\mathrm{Fe}$ significantly reduced $\mathrm{Zn}$ concentrations in the serum and femurs of dams. A previous study indicated that excessive amounts of dietary Fe decreased apparent intestinal $\mathrm{Zn}$ absorption in rats $^{26)}$. Plasma $\mathrm{Zn}$ concentrations rapidly declined in $\mathrm{Zn}$ depletion and femur $\mathrm{Zn}$ concentrations then significantly fell ${ }^{4)}$. The lowered Zn concentrations in femurs in the excessive $F e$ groups might be due to the decreased serum Zn concentrations caused by the reduced intestinal absorption of Zn.

The $\mathrm{Cu}$ deficient diet remarkably decreased the serum $\mathrm{Fe}$ concentrations and increased the liver $\mathrm{Fe}$ concentrations in dams fed excessive amounts of dietary $\mathrm{Fe}$. Evans and ABRAHAM $^{10)}$ reported that $\mathrm{Fe}$ mobilization from liver to serum in rats was disturbed by a low serum ceruloplasmin activity which resulted from a $\mathrm{Cu}$ deficient diet. The decrease in serum $\mathrm{Fe}$ concentrations and the increase in liver $\mathrm{Fe}$ concentrations caused by deficient 
dietary $\mathrm{Cu}$ in rats might have reflected the decline of Fe released from liver to serum. The Fe concentrations in whole bodies and livers of fetuses from dams fed excessive amounts of dietary $\mathrm{Fe}$ were also decreased by the $\mathrm{Cu}$ deficient diet for dams. The lowered serum $\mathrm{Fe}$ concentrations in dams caused by a low $\mathrm{Cu}$ status might have resulted in the decreased transfer of $\mathrm{Fe}$ from dams to fetuses.

In conclusion, the excessive amount of dietary $\mathrm{Fe}$ did not aggravate the Cu status in pregnant rats and their fetuses. However, the present study suggests that attention should be paid to Se, Mn and $\mathrm{Zn}$ statuses in dams and to Se and $M n$ statuses in their fetuses when the dams are fed a large amount of dietary Fe.

The study was supported by a grant for scientific research (No. 02954104) from The Ministry of Education, Science and Culture of Japan.

\section{References}

1) Ammerman, C.B. and M. Miller, Selenium in ruminant nutrition. A review. J. Dairy Sci., 58 : 1561-1577. 1975.

2) Apgar, J. and J.A. FitzGerald, Effect on the ewe and lamb of low zinc intake throughout pregnancy. J. Anim. Sci., 60: 1530-1538. 1985.

3) Bremner, I. and J. Price, The effects of dietary iron supplements on copper metabolism in rats. in Trace Elements in Man and Animals-5. (C.F. Mills, I. Bremner and J.K. Chesters, eds.) 374-376. CAB Press. Slough. 1985.

4) Brown, E.D., W. Chan and J.C. Sмith, Bone mineralization during a developing zinc deficiency. Proc. Soc. Exp. Biol. Med., 157 : 211-214. 1978.

5) Campbell, A.G., M.R. Coup, W.H. Bishop and D.E. Wright, Effect of elevated iron intake on the copper status of grazing cattle. N.Z.J. Agric. Res., 17: 393-399. 1974.

6) Coup, M.R. and A.G. CAmpBell, The effect of excessive iron intake upon the health and production of dairy cows. N.Z.J. Agric. Res., 7 : 624-638. 1964.
7) Davies, N.T. and R.B. Wrlliams, The effects of pregrancy on uptake and distribution of copper in the rats. Proc. Nutr. Soc., 35 : 4 A-5 A. 1975.

8) Dougherty, J.J., W.A. Croft and W.G. HoEKSTRA, Effect of ferrous chloride and iron-dextran on lipid peroxidation in vivo in vitamin $\mathrm{E}$ and selenium adequate and deficient rats. J. Nutr., 111: 1784-1796. 1981.

9) Dyer, I.A., W.A. Cassatt, Jr. and R.R. RAO, Manganese deficiency in the etiology of deformed calves. Bioseience, 14:31-32. 1964.

10) Evans, J.L. and P.A. Abraham, Anemia, iron storage and ceruloplasmin in copper nutrition in the growing rat. J. Nutr., 103 : 196-201. 1973

11) Gordon, D.T. and M. Ellersieck, The interactions among $\mathrm{Fe}, \mathrm{Zn}$ and $\mathrm{Cu}$ affecting liver $\mathrm{Cu}$ and femur $\mathrm{Zn}$ concentrations in the rat. in Trace Elements in Man and Animals-6. (L.S. Hurley, C.L. Keen, B.L ÖNNERDAL and R.B. RucKer, eds.) 181-182. Plenum Press. New York. 1988.

12) GRUDEN, N., Interrelationship of manganese and iron in rat's duodenum. Nutr. Rep. Int., 15 : 577 580. 1977.

13) HARVEY, W.R., User's guide for LSMLMW. 1-46. Ohio State University. Columbus. 1985.

14) Harrison, J.H., D.D. HanCOCK, and H.R. CONRAD, Vitamin $\mathrm{E}$ and selenium for reproduction of dairy cow. J. Dairy Sci., 67 : 123-132. 1984.

15) Hidiroclou, M., Trace elements in the fetal and neonate ruminant: a review. Can. Vet. J., $21: 328-335.1980$.

16) Hidiroglou, M. and J.E. Knipfel, Maternal-fetal relationships of copper, manganese, and sulfur in ruminants. A review. J. Dairy Sci., 64 : 1637-1647. 1981.

17) Kramer, T.R., W.T. Johnson and $M$. BRISKE-ANDERSON, Influence of iron and the sex of rats on hematological, biochemical and immunological changes during copper deficiency. J. Nutr., 118: 214-221. 1988.

18) Kriesten, K., W. Schmidtmann and U. Murawski, Iron and copper concentrations in the maternal and fetal serum, placenta and amniotic fluid during the reproductive stadium as well as in the milk of rabbits. 


\section{KUMAGAI, KaWASHIMA and YaNo}

Comp. Biochem. Physiol., 83 A : 291-296. 1986.

19) Lewis, G., S. Terlecki and R. Allcroft, The occurrence of swayback in lambs of ewes fed semi-purified diet of low copper content. Vet. Rec., 81: 415-416. 1967.

20) Romeu, A., M. Alemany and L. Arola, Net transfer of essential metals from mother to fetus in the second half of pregnancy in the rats. Biol. Neonate., 49 : 204-210. 1986

21) SARAN, M. and W. Bors, Radical reactions in vivo-an overview. Radiat. Environ. Biophys., 29 : 249-262. 1990.

22) Standish, J.F., C.B. AmMERMan, C.F. SIMPSON, F.C. NeAi and A.Z. PALMER, Influence of graded level of dietary iron, as ferrous sulfate, on performance and tissue mineral composition of steers. J. Anim. Sci., 29 : 496-503. 1969.

23) Stokey, M.L. and J.L. Greger, Iron, zinc and copper interactions: chronic versus acute responses of rats. J. Nutr. $117: 1434$ 1442. 1987.

24) Tawada, T., M. Kurabayashi, T. OKuyama and $H$. Furuya, Studies on the placental transport mechanism for iron. Acta. Obst.
Gynaec. Jpn., 37 : 735-742. 1985.

25) Underwood, E.J., Trace elements in human and animal nutrition. 4th ed. 37-39. Academic Press. New York. 1977.

26) VAlberg, L.S., P.R. Flanagan and M.J. Chamberlain, Effects of iron, tin and copper on zinc absorption in humans. Am. J. Clin. Nutr., 40 : 536-541. 1984.

27) Wallenburg, H.C.S. and H.G. EiJK, Effect of oral iron supplementation during pregnancy on maternal and fetal iron status. J. Perinat. Med., 12: 7-12. 1984.

28) WANG, Z.S. and D.G. MASTERS, Effects of supplementary iron on tissue trace elements and plasma folate and vitamin $\mathrm{B}_{12}$ in young sheep. Proc. Nutr. Aust., 15 : 142. 1990.

29) WatKinson, J.H., Fluorometric determination of selenium in biological material with 2,3-diaminonaphthalene. Anal. Chem., 38 : 92-97. 1966.

30) Wu, W-H., M. Meydani, S.N. Meydani, P.M. Burklund, J.B. Blumberg and H.N. MunRo, Effect of dietary iron overload on lipid peroxidation, prostaglandin synthesis and lymphocyte proliferation in young and old rats. J. Nutr., 120 : 280-289. 1990. 


\title{
飼料中の過剩量の鉄が娃娠ラットに及ぼす影響： 母親之胎児の鉄, 銅, 亜鈶, マンガンおよび セレンの栄養状態について
}

\author{
熊谷 元・川島良治* 知野秀雄 $^{*}$ \\ 広島大学生物生産学部, 東㕕島市 724 \\ * 京都大学農学部, 京都市左京区 606
}

\begin{abstract}
銅を適当量および久乏量与元られた妊娠ラットに対して過剩量の鉄を投与し，母親と胎児の微量元素 の栄養状態を調べた。平均 46 日齢のウィス夕ー系脽ラット 40 頭を，鉄適当量・銅適当量（鉄 43 $\mathrm{mg} / \mathrm{kg} \cdot$ 銅 $6.0 \mathrm{mg} / \mathrm{kg}$ ), 鉄遮当量・銅欠之量（鉄 $43 \mathrm{mg} / \mathrm{kg} \cdot$ 銅 $0.6 \mathrm{mg} / \mathrm{kg}$ ), 鉄過剩量・銅適当量 （鉄 $1165 \mathrm{mg} / \mathrm{kg}$ ・銅 $6.0 \mathrm{mg} / \mathrm{kg}$ ）および鉄過剩量・銅欠乏量（鉄 $1165 \mathrm{mg} / \mathrm{kg} ・$ 銅 $0.6 \mathrm{mg} / \mathrm{kg}$ ）の飼

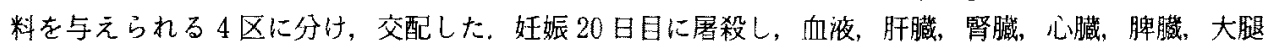
骨および胎兄を採取した，飼料中の過剩量の鉄は母親の肝臟と心臟の重量索低下させ，胎児 1 頭当りの 重量を增加させた，母親と胎児の組織中の鉄濃度は過剩军の鉄の投与によって增加した。 また, 過剩量

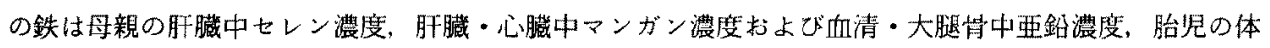
中セレン濃度および休中・肝臓中マンガン濃度を低下させたが、母親扔上び胎児の組織中の銅濃度を低 下させなかった。一方, 飼料中の欠乏量の銅は母親抬よび胎児の組織中の銅蕽度を低下させた，過剩量 の鉄を与えられた母ラットの血清中鉄濃度と胎児の体中・䀒臟中铁濃度は欠乏量の銅の投与によって低 下した。
\end{abstract}

